\title{
Carpel - fruit in a coniferous genus Araucaria and the enigma of angiosperm origin
}

\author{
Valentin Krassilov*, Sophia Barinova \\ Institute of Evolution, University of Haifa, Mount Carmel, Haifa 31905, Israel \\ Email address: \\ krassilo@research.haifa.ac.il (V. Krassilov), vakrassilov@gmail.com (V. Krassilov)
}

\section{To cite this article:}

Valentin Krassilov, Sophia Barinova. Carpel - Fruit in a Coniferous Genus Araucaria and the Enigma of Angiosperm Origin. Journal of Plant Sciences. Vol. 2, No. 5, 2014, pp. 159-166. doi: 10.11648/j.jps.20140205.13

\begin{abstract}
Reproductive morphology of araucarian samara is revised revealing a carpellate structure of the stone. In $A$. columnaris it is formed by a supercoiled spermophyll ('seed scale'), with a stigmatic apical lobe. This structure is analogous to the 'classical' peltate carpel of flowering plants. Stone opens with two apical pores. Pollen germinates on the apical stigmatic crest, with extracellular matter exuded from a stigmatic gland and its opposite on the bract apophysis. Ovulate structures are of the same basic type in the allied genera Wollemia and Pararaucaria. Neither of these genera is morphologically 'transitional' at the generic as well as familial levels thus setting araucarians apart from the rest of conifers no longer conceivable as a uniquely derived clade of gymnospermous plants. Araucarians thus deserve the status of a separate order anticipating the major evolutionary advancements of angiospermy in flowering plants.
\end{abstract}

Keywords: Plant Morphology, Paleobotany, Conifers, Araucariaceae, Carpel, Angiosperm Origin, Fossil Gymnosperms, Evolutionary Parallelism

\section{Introduction}

The lingering problem of angiosperm origin is in part semantic, the angiosperms, or flowering plants being defined as having carpels and flowers, while carpels and flowers are defined as reproductive structures uniquely derived in angiosperms (flowering plants). Gymnosperm ovules can be surrounded by an envelope of a sort, such as scale complex, cupule, aril, epimatium, whatever, but not carpel for which angiosperms are granted an exclusive right (discussed in [1]). It is insistently recommended by editors and reviewers to keep angiosperm morphological terminology separate from that of gymnosperms in order to prevent any sweeping ideas on their non-cladistic relationships.

Let us make it clear from the beginning: I am not deriving angiosperms from Araucaria (neither had I ever derived the angiosperm family Asteraceae from Mesozoic bennettites on the basis of their achene homologies). Yet an extraovular structure enclosing the ovule and providing a platform for pollen reception and germination is carpel whatever the currently endorsed taxonomy implies. Taxonomy is an outcome of comparative morphology rather than the other way round, or we would stick forever in a basic confusion eloquently represented as a great evolutionary mystery.
This paper is on the carpellate structures in Araucaria for which there is no reason for not being called carpel. To explore its bearing on seed plant phylogeny the extant morphology and the fossil record of Araucariaceae has to be critically reconsidered.

\section{Material and Methods}

Reproductive material was obtained from A. columnaris (G. Frost) Hook., cultivated as decorative tree in Haifa. The tree sheds short shoots, pollen cones, and seed cone samaras, thus abundantly available. The species is native to New Caledonia where it is known as columnar araucaria ('pine') or Cook araucaria ('pine'). It is considered synonymous to $A$. cookii $\mathrm{R}$. $\mathrm{Br}$., the much smaller scales of which from native herbarium material have been studied for comparison.

The fossil material used in this paper for elucidating the historical dimension of carpellate structures in the Araucariaceae is courteously provided by Flavio Bacchia (Trieste, Italy), representing small silicified cones known under commercial name 'pinecones'. Their geological age is a pending problem, usually given as Eocene, but more probably Cretaceous. Their full morphological description and taxonomic treatment will be given elsewhere after 
clarification of this stratigraphic problem.

Cuttings are made from untreated material or for the extant material after brief immersion in nitric acid for softening sclerenchymous tissues and making coalescent parts more readily separable. Resin is removed from interior cavities by immersing in alcohol for about an hour. Photographs are made with the Leica stereomicroscope, Nikon Eclipse light microscope, and the EF1 Quanta 200 scanning electron microscope (SEM).

\section{Results}

Araucaria columnaris is a large tree with helically arranged regularly spaced sparsely branched crown twigs bearing pendulous cord-like ultimate shoots that flicker and quiver like aspen leaves under gentle wind. The ultimate shoots are replaced through year, shed in masses during the drier season. Male cones are pendulous, shed intact. In contrast, seed cones are erect, ovoid, disintegrating at maturity unless torn off by wind from upper branches (Fig. 1). The seed-bearing structures are arranged in a tight spiral, with parastichi compressed, appearing nearly verticillate.

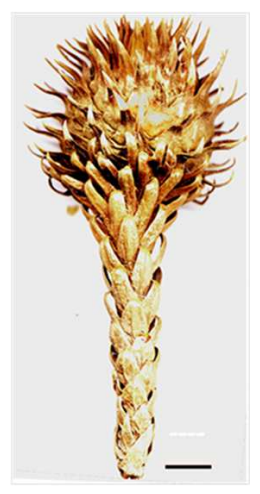

Figure 1. Araucaria columnaris: immature cone; scale bar $1 \mathrm{~mm}$.

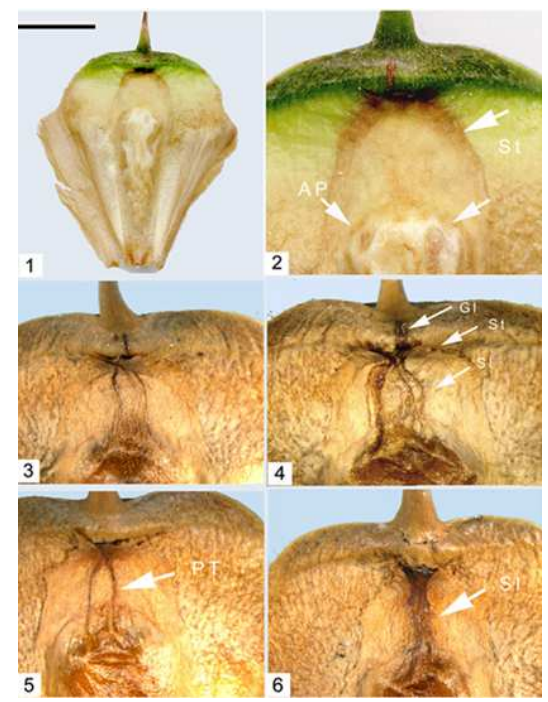

Figure 2. Araucaria columnaris: 1, 2, samara, showing stigmatic lobe (St) and pits marking the apical pores of the stone (AP); $3-6$. Apical lobe ('ligule') showing stigma-like fringe (St), style-like median ridge (Sl), pollen tube tracks (PT), and a vis-à-vis gland (Gl) on the bract apophysis; scale bar $10 \mathrm{~mm}$.
The seed-bearing structures are broadly cuneate samaras with two laterally symmetrical membranous wings forming broad shoulders (up to $25 \mathrm{~mm}$ ) below the thickened apophysis (Fig. 2-1, 2-2). The apophysis is green in freshly shed samaras and is strewn with abundant stomata on the adaxial surface. It represents the free part of a bract subtending the fertile structure ('seed scale'). A dentate flap adjoined to the bract below the apophysis is called ligule (Figs 2-3 - 2-6.), commonly interpreted as a free part of the 'seed scale', the rest of it being fused to the bract.

The median area of the bract - seed scale complex is occupied with a hard obovate body, commonly interpreted as a massive inverted seed embedded in the coalescent tissues. Although habitually referred to in morphological descriptions, the mechanism of 'embedding' was never elucidated. The idea of 'embedding' is here challenged on the basis of surface morphology, cuticle extension, and what is seen on transverse cuttings of the hard body (stone) of the samara.

The stone is attenuated to a stalk-like base. The broad summit shows irregular protuberances around two prominent pores (Figs. 2-1, 5-2), similar to the apical germination pores of angiosperm fruits such as the poricidal capsules of Papaver or Nigella. It is shown later in the paper that in both extant and fossil material embryo emerges through an apical pore.

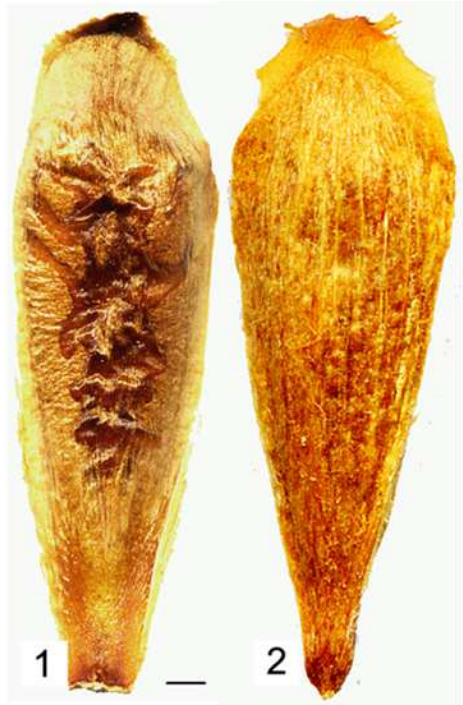

Figure 3. Araucaria columnaris: carpellate stones, adaxial (1) and abaxial (2) views; scale bar $2 \mathrm{~mm}$.

The stone wall is formed of thick sclerenchyma hardened with resin. The exposed adaxial surface of stone is clad with cuticle continuous with the cuticle of ligule that forms an apical sterile extension of the stone (a groove between stone and 'ligule' is due to their different hardness alone). Stone is readily separable, together with ligule, from the adjacent bract tissue. Its adaxial surface is rather heavily cutinized, the cuticle being crumpled and folded with sclerification underneath; the abaxial surface is devoid of cuticle showing parallel vascular bundles traversing fibrous sclerenchyma of the wall, the fibers extending to the ligule (Fig. 3). 


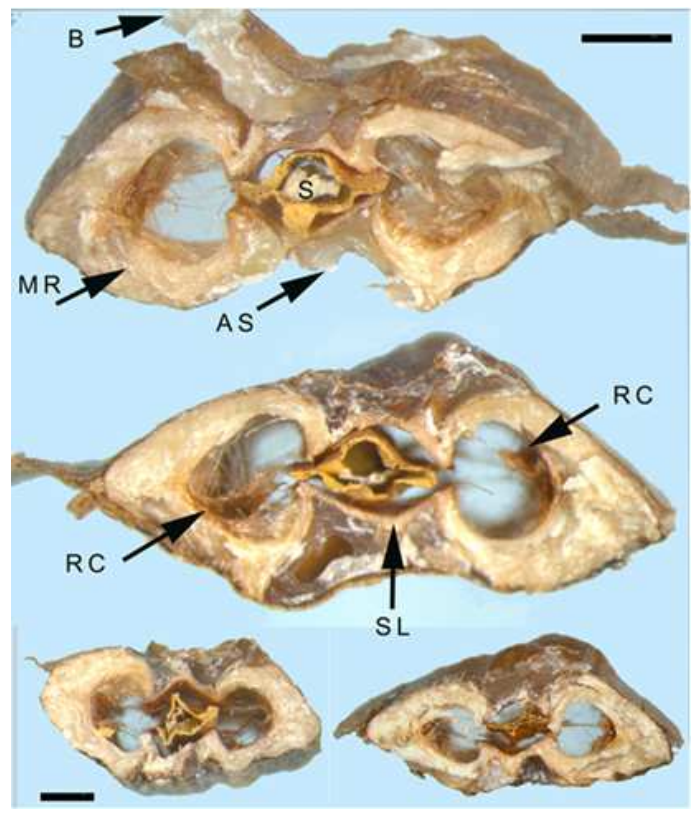

Figure 4. Araucaria columnaris: transverse sections of carpellate stones showing supervoluted margins of the carpel ('seed scale'), sealed with resinous pads on the bract (B) side and adaxial suture (AS), forming marginal rolls (MR) lined with cuticle ( $R C)$ on the inside. Central locule (SL) contains a thick-walled seed (S) with narrow wing-like extensions; scale bar $1 \mathrm{~mm}$.

Transverse cuttings across the stone show its hard wall being plicate over the midline on both adaxial and abaxial sides (Fig. 4). On both sides of the adaxial plica the wall is supercoiled (doubly revoluted toward the abaxial side) forming two marginal rolls lined with cuticle continuous with that of the stone surface on the outside and likewise readily detachable. The rolls are hollow or filled with a cobweb of slender resin threads. Proximally the walls of the juxtaposed rolls form a seed locule in the middle of the stone. The locule is sealed with resinous pads of sclerenchyma over the median suture.

In cross-section, the locule is triangular or irregularly angular, shaping the seed that is spindle-formed with a long micropylar tube, stretching from two thirds to three quarters the length of the locule, broadest in sagittal plane, with rudimentary lateral wings penetrating narrow slits of the marginal coils (Figs. $4-6$ ). The seed is thick-walled, irregularly ridged, either barren with a collapsed cavity or containing an embryo at various developmental stages. Example in Fig. 6 shows a split seed apex containing a small globose endosperm of bulging starch cells. It is traversed with a linear embryo extended as a radicle down the micropyle and as a slender whipcord-like hypocotyl heading toward an apical pore and producing halfway two (or sometimes solitary) narrow lanceolate cotyledons (Fig. 7).

The nature of the stone emerging from these observations is of a hard sclerenchymatous extraovular structure ('seed scale') doubly coiled to form three inner cavities lined with cuticle: two marginal rolls and the axial tunnel-like seed locule between them. The median plicae (sutures) between the rolls are filled with resin pads. The stone opens with apical pores initially covered with surface cuticle. Embryo undergoes initial differentiation within the locule and grows toward an apical pore.

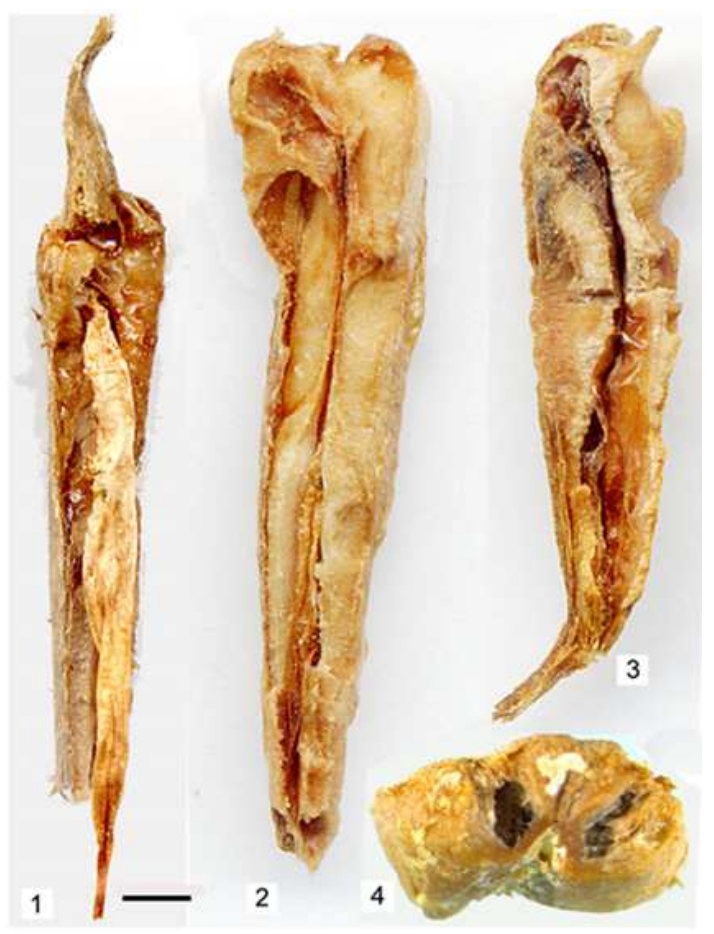

Figure 5. Araucaria columnaris: 1 - 3, stones split in sagittal plane, showing seed (1) and the cuticle lined seed locule (2, 3); 4 - stone apical pores; scale bar $2 \mathrm{~mm}$.
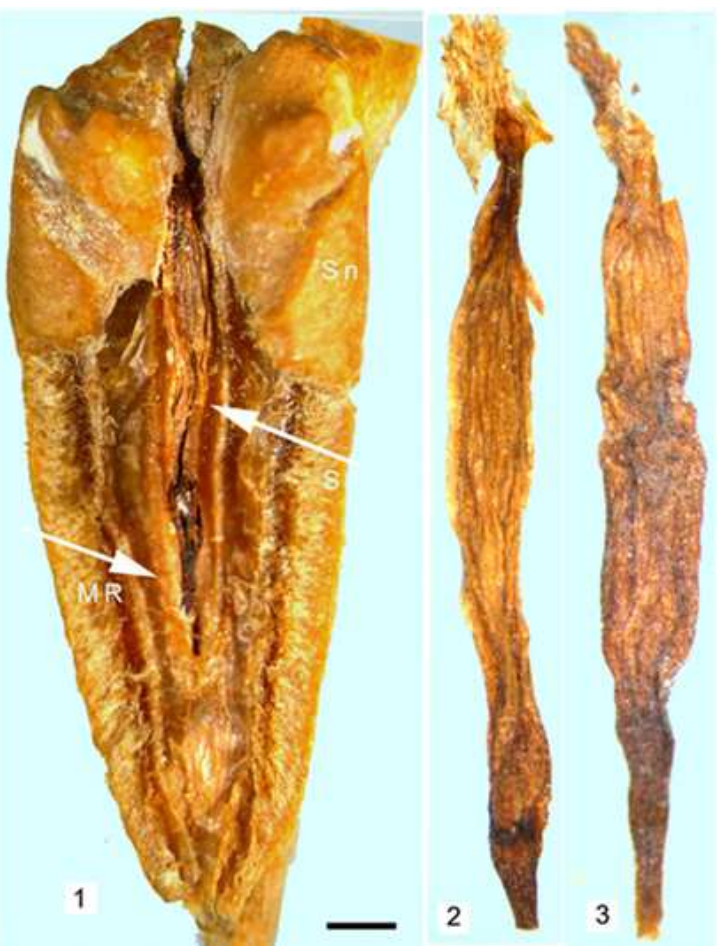

Figure 6. Araucaria columnaris: 1, Stone split longitudinally, with the apical part retained $(S N)$; seed $(S)$ is visible in a slit-like locule, bordered by the marginal rolls (MR) of the carpelloid seed-scale; scale bar $2 \mathrm{~mm}$. 


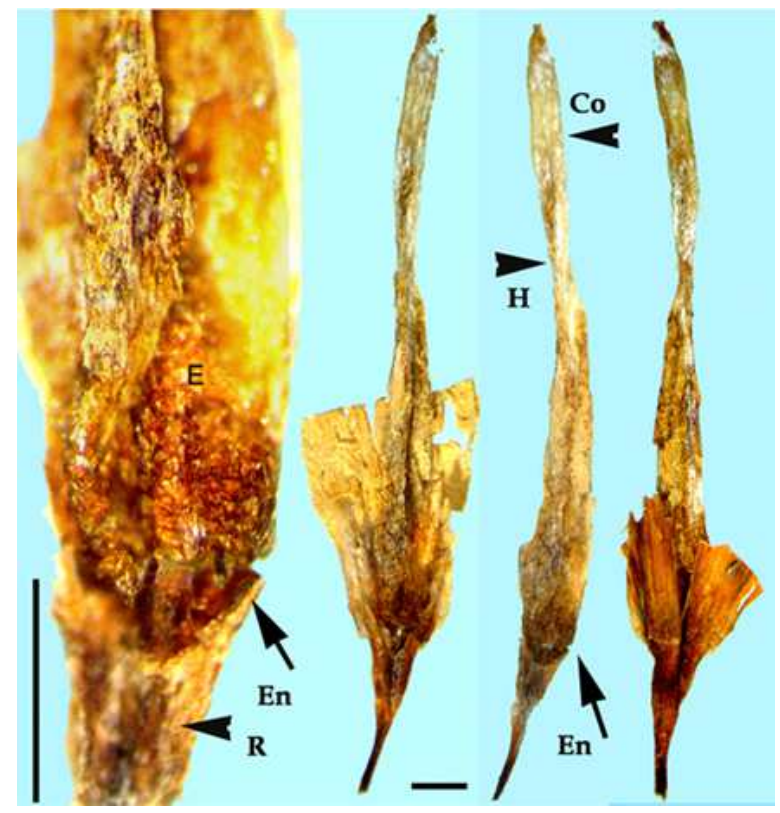

Figure 7. Araucaria columnaris: apical part of seed containing endosperm $(E n)$ and protruding embryo (E), with a slender hypocotyl $(H)$, radical $(R)$ and cotyledon (Co); scale bar $1 \mathrm{~mm}$.

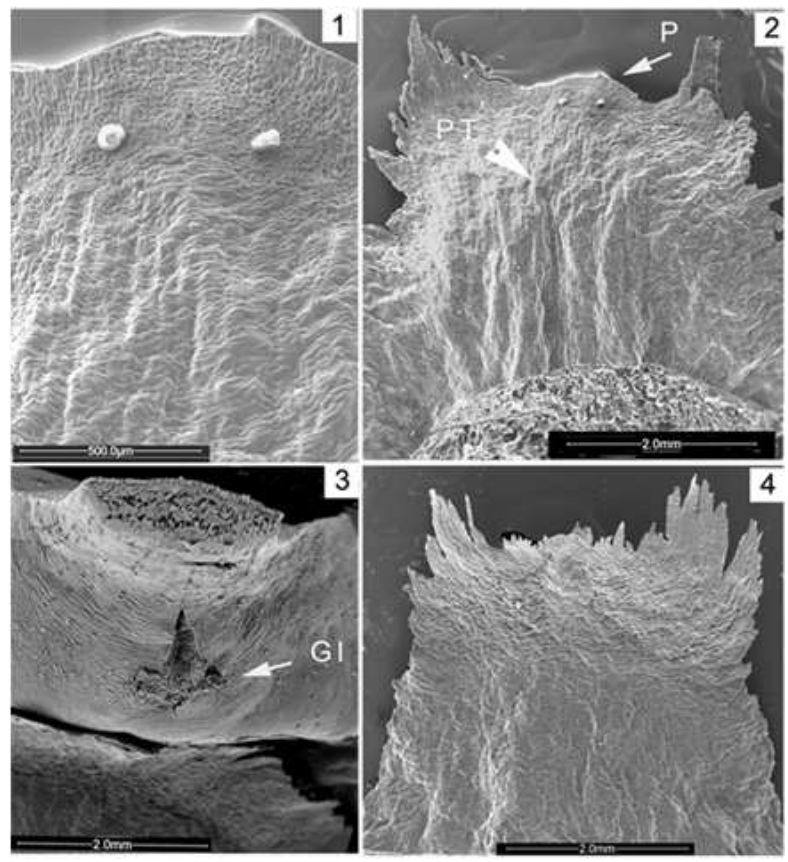

Figure 8. Araucaria columnaris: Stigmatic lobes, some with pollen grains $(P)$ attached, and pollen tube tracks (PT); also showing a prominent gland (GL) on the bract apophysis (3); SEM.

The 'ligule' is a thick but relatively soft sterile extension of the stone adnate to the bract apophysis, but never fused to it, scoop-shaped of variable length, adhering the whole length or slightly diverging at the apex. The membranous marginal fringe is a serrate crest of delicate teeth increasing and spreading fan-like toward the apex. The teeth are longer on flanks, modified in the middle into a solid gland, impregnated with a resinous exudate that, as Fig. 8-3 suggests, may come from a large gland developing on the bract apophysis immediately above the ligule. Pollen grains regularly occur on the fimbriate fringe, mostly as bunches of collapsed exines (Fig. 8-1), but some irregularly slit over the equator at the beginning of germination process (Fig. 9). Pollen tubes appear erosive, leaving a straight or broadly bowed track in the epidermis of thin-walled interlocked cells (Fig. 8-2).

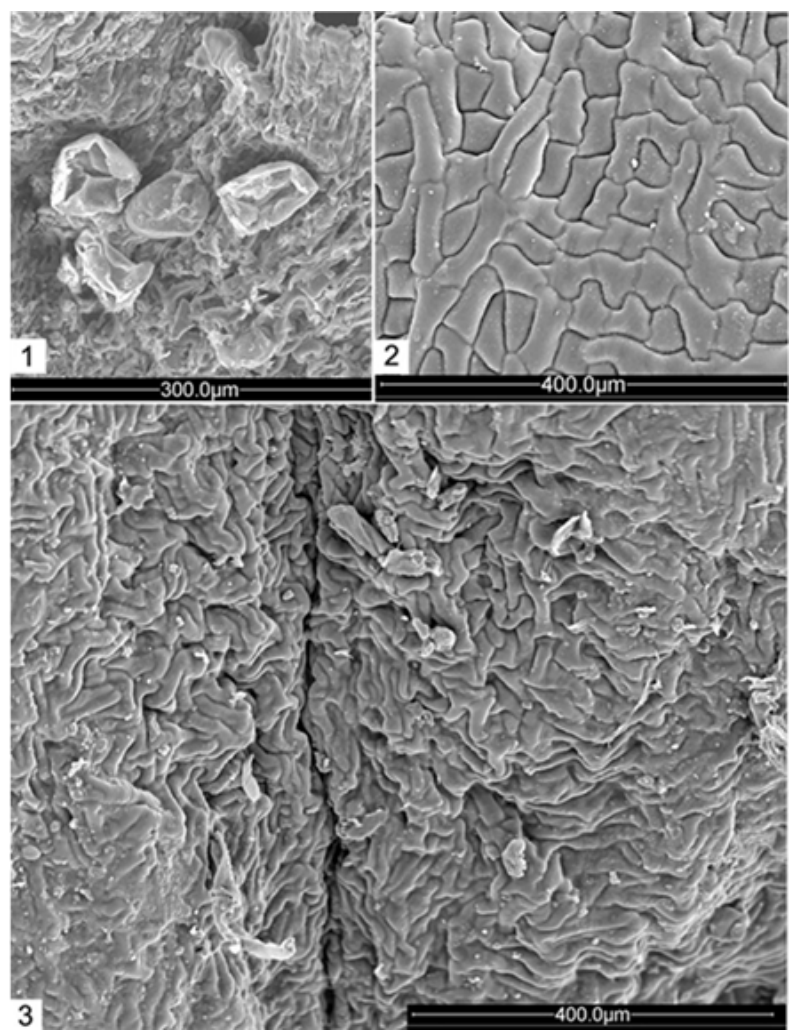

Figure 9. Araucaria columnaris: 1, pollen grains on stigmatic crest; 2. interlocked epidermal cells of the style region; 3, Track of pollen tube down the stigmatic lobe; SEM.

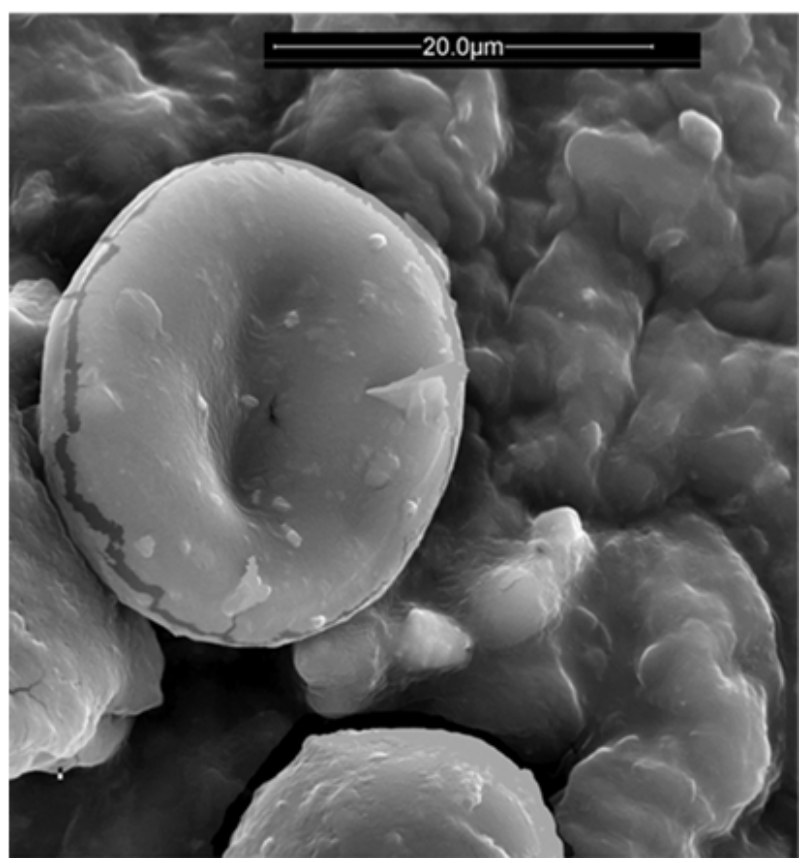

Figure 10. Araucaria columnaris: germinate pollen on the stigmatic crest, SEM 
In the small-scaled araucarians with samaras ca. $10 \mathrm{~mm}$ across (Fig. 11), the stone is feebly sclerified and less readily detachable, with less prominent marginal rolls, but fruit-like as in the larger samaras (above), formed by the carpellate 'seed scale' mainly. The adaxial part separated by splitting over the median plane (Fig. 11-3) has a relatively long styloid part crowned with a serrate stigmatic crest. The stone is elliptical, with the counterpart attached to the bract showing a slender elongate seed between the lateral coils of the carpel wall.

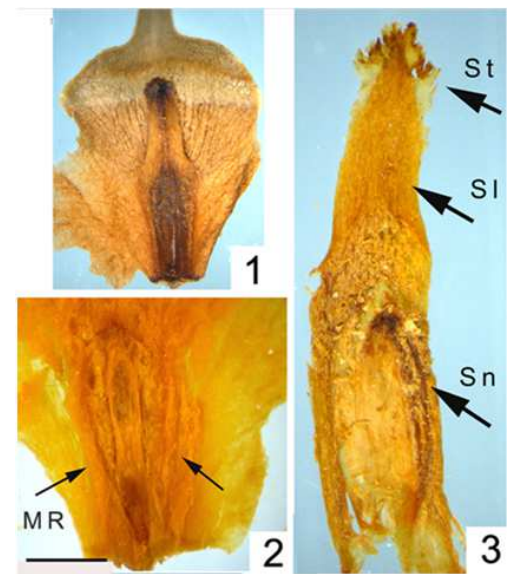

Figure 11. Small-scaled Araucaria, samara (1) cleared and split to expose the stone parts attached to the opposite walls of the carpelloid seed scale $(2,3)$, with the adaxial part showing long style (Sl), stigma (St), and stone (Sn), while the marginal rolls (MR) are better seen on the opposite part; scale bar $3 \mathrm{~mm}$.

In a large-scale species $A$. bidwillii, cones are sometimes shed intact (this phenomenon seems climatically controlled). Ripe stone is separated from the bract and the ligule. It occasionally contains two seeds. External wall is separated from the seed with a fibrous felt-like layer (mesocarp). Shed stone is filled with endosperm resorbing the seed coat. Embryo is immersed in endosperm and poorly differentiated in comparison with $A$. columnaris.

Fossil araucarian remains are widespread, represented by impressions - compressions mostly, but a few localities like Cerro Cuadrado Petrified Forest of Patagonia contain silicified material providing structural details. A recently found comparable material from western Sahara contains abundant silicified cones, elongate, ranging from 20 to $50 \mathrm{~mm}$ in length, consisting of hundreds spirally attached densely packed ovulate structures seen on the cone surface as an amour of rhombic apophyses with a median groove and two lateral pits (Fig. 12). Abaxially it is fringed with a protruding crescent-shaped hairy rim corresponding to the stigmatic apical lobe of $A$. columnaris, but the surface is abraded and only a scar of vascular trace marks the position of a slender awn. The radially cut ovulate structures are goblet-shaped and far more delicate than stones of $A$. columnaris described above. However, the surface pits are shown to be apical pores of two marginal rolls, while the median part is a locule, with a seed preserved as a solid elliptical body (Figs. 13, 14). Its flat-top endosperm infilling expands up to two thirds of the goblet or reduced to a small globose mass at the bottom. Embryo is sometimes visible in the middle of endosperm and protrudes through a deformed apical pore. The well-preserved cellular features will be described elsewhere.
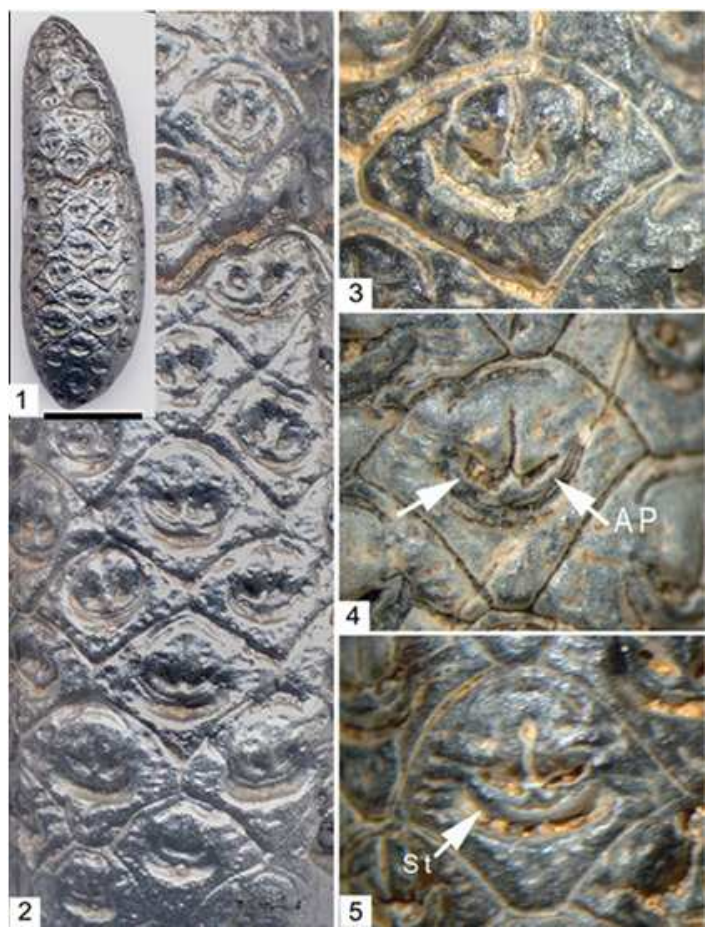

Figure 12. Pararaucaria sp.: 1 -5. a silicified cone with scale apophyses showing two pit marks of the stone apical pores (AP); the apical stigmatic lobe (St) is also discernible; scale bar $10 \mathrm{~mm}$.

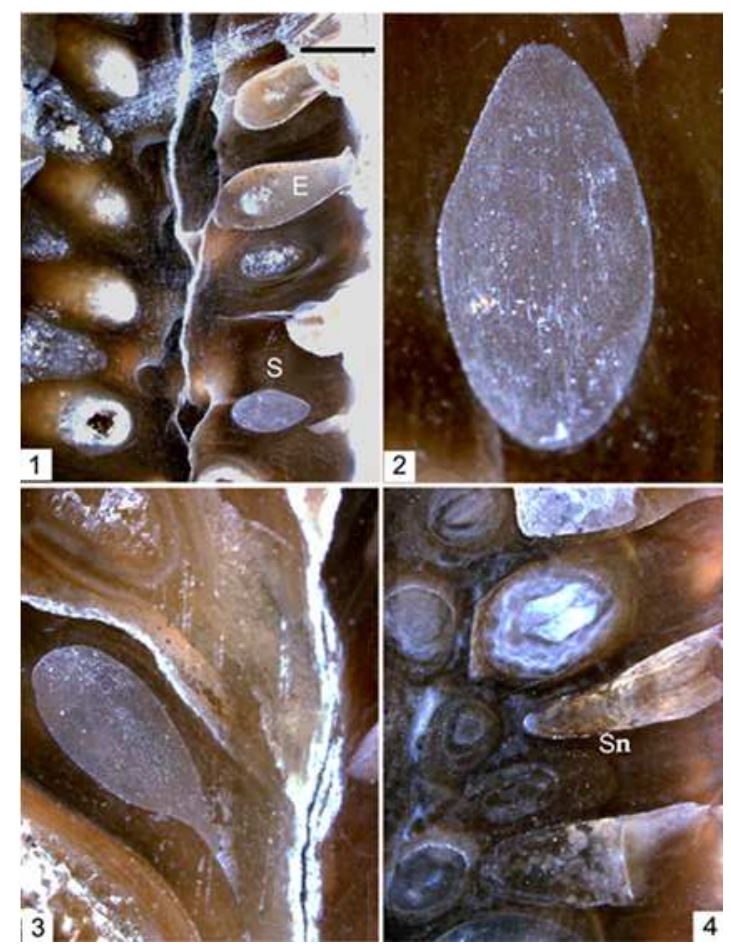

Figure 13. Pararaucaria sp.: $1-4$, sections showing seeds (S) and stones (Sn) filled with endosperm (E); scale bar $2 \mathrm{~mm}$. 


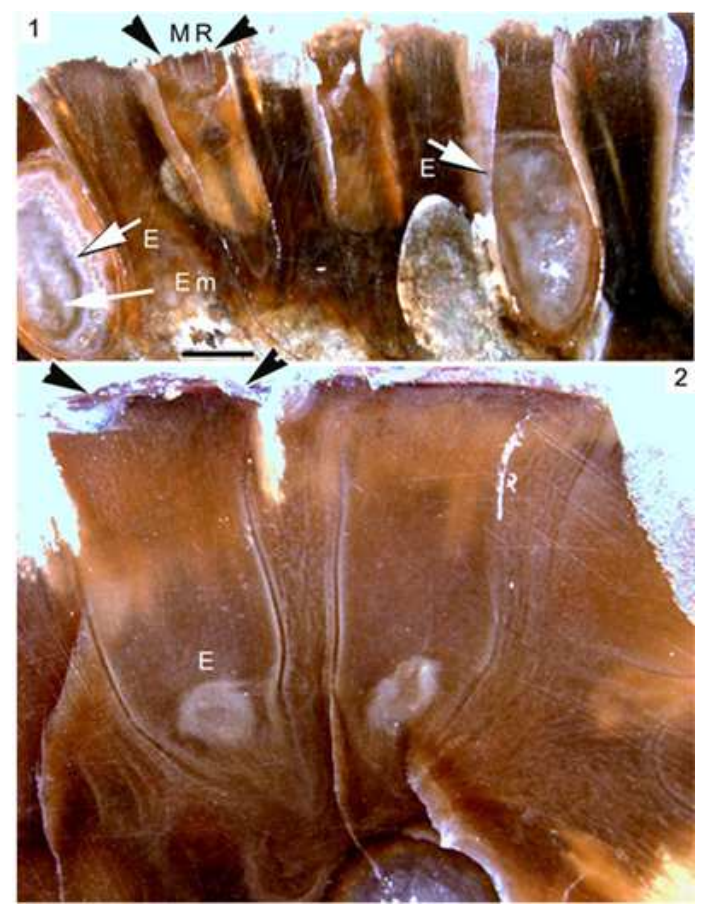

Figure 14. Pararaucaria sp.: 1, 2, sections showing marginal rolls (MR, arrowheads) and massive endosperm (E), some with developing embryo (Em); scale bar $1 \mathrm{~mm}$.

\section{Discussion}

Thus the stone of samara in Araucaria columnaris is not seed as it is traditionally interpreted, but a morphologically elaborate extraovular structure consisting of a tubular adaxially plicate unilocular fertile part overtopped by a sterile stigmatic lobe, thus corresponding to a peltate type carpel common in the ranunculid angiosperms [2-8. reviewed in 9, $10]$.

The origin of peltate carpel is a matter of lingering discussion, with both spermophyll and cupule considered as possible prototypes. Traditionally it is thought to be derived from a laminar fertile organ, 'megasporophyll' or spermophyll (represented by 'seed scale' in conifers), conduplicate or voluted or else transformed through these both vernation modes combined. Involution is the most widespread mode, but revolution (wounding toward abaxial side) also occurs (for instance in Cercidiphyllum [9]). Like in Cercidiphyllum, the carpel margins are supervoluted (double-coiled) in $A$. columnaris, forming hollow lateral rolls on both sides of the locule serving as buttresses of the seed, thus forming a durable but light framework facilitating dispersal by air or water. The carpelloid stone is attached to the bract along the abaxial suture, whereas the adaxial suture is sealed by a pad of resinous matter. In comparison, peltate carpels of angiosperms can be open in early developmental stages, sealed later in development or incompletely so, horse-shoe shaped in transverse section.

In the light of these morphological data, the phylogeny and evolutionary history of the Araucariaceae, an ancient group of living coniferoids, has to be reconsidered, which requires a revision of its fossil record, presently a matter of morphological confusion. Traditionally, the stone of araucarian samaras is described as seed, whereas the structures within it are thought to be prothallial ('megagametophyte') or embryonic ('cotyledons'). It must be noted on account of a constant terminological confusion that in seed plants gametophyte develops in ovule; in seed, the remnants of it may contribute to nutrition tissue, the primary endosperm of whatever origin. In the samaras of $A$. columnaris, the endosperm is mostly exhausted, sometimes remaining as a small globose body near the micropylar end, from which an embryo with a radicle growing down the micropyle and hypocotyl heading toward an apical pore of the stone; the two cotyledons (sometimes a solitary one) are diverging midway. But the amount of endosperm and the extent of embryo differentiation within the seed vary widely through the genus.

It is well known that in the Araucariaceae and occasionally in other conifers pollen grains germinate on cone scales producing syphonogamous pollen tubes $[10,11]$. However, in Araucaria columnaris we observed a more subtle and specialized device than is commonly expected of a conifer. The apical stigmatic lobe is rather massive, although not as massive relative to the ovary as in Hippophae rhamnoides (Elaeagnaceae), in which pollen tube traverses 'a prominent, ventrally localized dry and non-papillate stigma, a pseudostyle and a dorsally protruded superior ovary' [12]. Pollen tube approaches the solitary ovule through a pore in the carpel. Further points of resemblance are subepidermal pollen tube path in the stigmatic region, inciting the cells en route to exude an extracellular matter (ECM) that apparently facilitates tube growth.

The hypothesis of free flowing ECM being basic in angiosperms (critically reviewed in [13]) is favored by the peculiar mechanism of ECM production in Araucaria columnaris, where it is supplied by a vis-à-vis gland on the inner side of the bract apophysis. Insofar as stigmatic structures and pollen transmission tissues are generally considered to be a chief evolutionary innovation of great advantage in struggle for life with other plants, such as conifers for example, it seems worth noting that a similar and scarcely less efficient mechanism in A. columnaris, probably a parallel development, has not secured this magnificent tree a pedestal among the favorites of natural selection, although it is fairly successful as a native of an exceptionally diverse piece of plant life gratified by its inspiring presence.

The problem of morphological interpretation became more acute with the discovery of Wollemia, supposedly intermediate between Araucaria and Agathis in respect to ovulate structures, readily confirmed by molecular data. However, the figures presented in [14] suggest a separable stone exactly like one in Araucaria, with practically identical apical lobes. The interior structures are the same (and similarly confused by traditional interpretation). One therefore cannot help being somewhat skeptical about the coincidence of morphological and molecular data in the case.

Evolutionary approach implies intermediate or transitional states, but in the case of Araucaria and allies it is somewhat 
overdone, in particular when fossil finds are concerned. Some fossils previously thought to be Araucaria are presently reassigned to new genera transitional to Wollemia, the tendency encouraged by the lack of definite distinctions in ovulate structures of the two [15].

Taxonomic assignments and evolutionary history are regularly biased in favor of precarious morphological interpretations. Thus [16] allegedly established that northern araucarians got extinct in the Maastrichtian, which required discrediting the geologically younger records, such as in [17], on the pretext that the seeds are $5 \mathrm{~mm}$ long and ribbed, thought to be entirely different from the araucarian, but in fact typical of the small scale species of extant Araucaria.

Fossil genus Pararaucaria was described as transitional between Araucariaceae and Pinaceae, Araucariaceae and Taxodiaceae (Cupressaceae s. 1.), Taxodiaceae and Cherolepidiaceae, etc. [18 - 22]. Taylor et al. [23] went even further, assigning it to a new monotypic family Pararaucariaceae which, despite the name, has little in common with Araucariaceae, but is 'transitional' between the Pinaceae and Cupressaceae. Ironically, this new family is illustrated in their book by reference to their Fig. 21.125 that is captioned as representing Araucaria mirabilis, which is probably what it is. On the other hand, I see no principle difference between the type species and the Saharan material described above, which agrees with Araucaria as here interpreted, having a tubular stone with relatively prominent apical pits, sometimes interpreted as representing 'two seeds'. The scale rolls are also misinterpreted as coiled wings of a solitary seed. The seed development and endosperm content vary over the cone that was shed intact and probably remained so through embryogenesis. This feature correlates with a reduction of bract that apparently lost its wing or most of it. Pararaucaria is perhaps the most angiosperm-like representative of extinct Araucariaceae, with its fruit-like cones having morphological analogues among polycarpic magnoliids.

At the same time, Araucaria and allies is fairly distinct from the rest of conifers, suggesting contributions from more than one phylogenetic source. Since classical work by Rudolf Florin, the coniferous spermophyll ('seed scale') is interpreted as a flattened axial shoot, but strong evidence in favor of this hypothesis come from the Paleozoic Lebachiaceae alone, morphologically closer to cordaites ('microphyllous cordaites') than modern conifers as far as reproductive morphology is concerned.

\section{Conclusion}

Reinterpreted according to unbiased morphological evidence (so far incomplete because not all extant and fossil species are properly studied), the Araucariaceae is a peculiar group of gymnosperms of the ordinal taxonomic rank (Araucariales) a distinctive feature of which is the carpellate structure formed by revolute spermophyll with a sterile glandular apical extension acquiring the pollen reception function and facilitating an extraovular growth of pollen tubes.
The dispersal structure is fruit-like, with a hard stone of extraovular origin, having a layered wall with apical pores, and subtended by a persistent or deciduous bract. Such features thought typical of angiosperms are thus preempted by a more ancient group of Mesozoic seed plants. These and similar findings suggest reconsideration of the presently obligatory cladistic approach based on the assumption of uniquely derived characters. No characters can be a priory accepted as uniquely derived. What is acquired by one plant group is potentiated in the other groups of a broad structural grade like 'seed plants' and can be realized when functionally opportune.

\section{References}

[1] V. Krassilov, Angiosperm origins: morphological and ecological aspects. Sofia: Pensoft, May 1997, 270 pp.

[2] W. Troll, "Morphologie der schildförmigen Blätter,“ Planta, vol. 17, pp. 153-314, 1932.

[3] H. Baum, "Der Bau des Karpellstiels von Grevillea thelamanniana und seine Bedeutung für die Beteilung der epeltaten Karpelle,“ Phytomorphology, vol. 2, pp. 191-197, 1952.

[4] W. Leinfellner, "Beiträge zur Kronblattmorphologie VIII. Der peltate Bau der Nektarblätter von Ranunculus, dargelegt anhand yener von Ranunculus pallasii Schlecht,“ Östr. Bot. C., Bd. 105, S. 184-192, 1958.

[5] O. Rohweder, "Karpellbau und Synkarpie bei Ranunculaceen," Ber. Schweiz. Bot. Ges., vol. 77, pp. 376-432, 1967.

[6] M. Guédés, "Carpel peltation and syncarpy in Coriaria ruscifolia L.," New Phytol., vol. 70, pp. 213-227, 1971.

[7] F. Weberling, Morphology of flowers and inflorescences. (Translated by R. J. Pankhurst). New York: Cambridge University Press, 1989.

[8] X.-L.Yan, Y. Ren, X.-H. Tian, and X.-H. Zhang, "Morphogenesis of pistillate flowers of Cercidiphyllum japonicum (Cercidiphyllaceae)," J. Integrative Plant Biol., vol. 49(9), pp. 1400-1408, 2007.

[9] V. Krassilov, Cercidiphyllum and fossil allies: morphological interpretation and general problems of plant evolution and development. Sofia-Moscow: Pensoft Publishers, 2010, 151 pp.

[10] R. J. Haines, N. Prakash, and D. G. Nikles, "Pollination in Araucaria Juss," Australian J. Bot., vol. 32, pp. 583-594, 1984.

[11] J.N. Owens, T. Takaso, and C. J. Runions, "Pollination in conifers," Trends in Plant Science, vol. 3, pp. 479-485, 1998.

[12] Y. Mangla, R. Tandon, S. Goel, and S.N. Raina, "Structural organization of the gynoecium and pollen tube path in Himalayan sea buckthorn, Hippophae rhamnoides (Elaeagnaceae)," AoB PLANTS, vol. 5, pp. 1-11, 2013.

[13] T. L. Sage, K. Hristova-Sarkovski, K. Koehl, J. Lyew, V. Pontieri, P. Bernhardt, P. Weston, S. Bagha, and G. Chiu, "Transmitting tissue architecture in basal-relictual angiosperms: implications for transmitting tissue origins. Amer," J. Bot., vol. 96(1), pp. 183-206, 2009. 
[14] T. C. Chambers, A. N. Drinnan, and S. McLoughlin, "Some morphological features of Wollemi pine (Wollemia nobilis: Araucariaceae) and their comparison to Cretaceous plant fossils," Int. J. Plant Sci., vol. 159 (1), pp. 160-171, 2006.

[15] M. E. Dettmann, H. T. Clifford, and M. Peters, "Emwadea microcarpa gen. et sp. nov.-anatomically preserved araucarian seed cones from the Winton Formation (late Albian), western Queensland, Australia," Alcheringa, vol. 36 (2), pp. 217-237, 2012.

[16] R. W. J. M. van der Ham, J.W.M. Jagt, S. Renkens, and J. H. A. van Konijnenburg-van Cittert, "Seed-cone scales from the upper Maastrichtian document the last occurrence in Europe of the Southern Hemisphere conifer family Araucariaceae," Palaeogeography, Palaeoclimatology, Palaeoecology, vol. 291, pp. 469-473, 2010 .

[17] V. A. Krassilov, Tsagayan flora of the Amur Province. Moscow: Nauka, 1976, 92 pp.

[18] G. R. Wieland, "The Cerro Cuadrado petrified forest," Publ. Carnegie Inst. Washington, vol. 449, 1935.
[19] M.G. Calder, "A coniferous petrified forest in Patagonia," Bull. Brit. Mus. (Nat. Hist.) Geol., vol. 2, pp. 99-138, 1953.

[20] R. Stockey, "Reproductive biology of the Cerro Cuasrado (Jurassic) fossil conifers: Pararaucaria patagonica," Amer. J. Bot., vol. 64(6), pp. 733-744, 1977.

[21] R. A. Stockey, J. Kvaček, R. S. Hill, G. W. Rothwell, and Z. Kvaček, "Fossil record of Cupressaceaea s. lat." in A. Farjon, Ed. A monograph of Cupressaceae and Sciadopitys, pp. 54-68. Kew, Royal Botanical Gardens, 2005.

[22] A. R. T. Spencer, P. Kenrick, D. C. Steart, R. J. Garwood, J. Hilton, M. C. Munt, and J. Needham, "An exceptional three-dimensionally preserved Pararaucaria (Cheirolepidiaceae) ovuliferous cone from the Late Cretaceous of southern England: non-destructive recovery of full anatomical and histological detail using Diamond Light Source synchrotron," Abstract Book of the 9th European Palaeobotany - Palynology Conference, Padova, Italy, 26-31 August, 2014, pp. 255-256.

[23] T. N. Taylor, E. L. Taylor, and M. Krings, Paleobotany: The biology and evolution of fossil plants. Amsterdam: Academic Press, Elsevier, 2009, 1252 pp. 